\title{
Openness of Public Information in the Management of Village Funds in North Minahasa Regency
}

\author{
Sisca B. Kairupan* \\ State Administration Study Program \\ Faculty of Social Sciences, \\ Universitas Negeri Manado \\ Manado, Indonesia \\ siscakairupan@unima.ac.id
}

\author{
Jeane Mantiri \\ State Administration Study Program \\ Faculty of Social Sciences \\ Universitas Negeri Manado \\ Manado, Indonesia \\ jeanelitha@unima.ac.id
}

\begin{abstract}
This research aims to 1). Describe, analyze, interpret public information disclosure in North Minahasa Regency; 2). To analyze what factors are hampering the disclosure of public information in North Minahasa Regency. The research technique used is descriptive qualitative. The study was located in North Minahasa Regency. Based on the results of the study, it was concluded that in Permandagri 113/2014 regarding village financial management has not been applied in managing village funds in North Minahasa Regency and the socialization conducted by the North Minahasa District Government regarding the management of village funds has not been effective so that the government and village communities have not understood correctly about contents of Permendagri 113/2014 concerning village financial management.
\end{abstract}

Keywords: Public Information, Implementation, Village Fund

\section{INTRODUCTION}

Information is the need to obtain knowledge for everyone. Information is needed by everyone to develop and broaden their horizons in order to know various changes or developments, especially for the community in their social environment. Information is also the most important part in communicating, because without good information a person cannot communicate well, it is difficult to do something related to society or it will even be difficult to explore the world in the sense of being difficult to adapt and someone will find it difficult to develop themselves towards a better.

Openness of public information is an inseparable aspect of democracy that upholds freedom and human rights in the fulfillment of individual or individual rights. Openness of public information is a means of optimizing public oversight of the administration of the State and other public bodies and everything that results in the public interest. In Indonesia, recognition of access to information as a human right is stated in the constitution of the 1945 Constitution in article 28 (f) and Law No.39 article 14 of 1999 concerning human rights, stating that everyone has the right to communicate and obtain information for develop personal and social environment, and have the right to seek, obtain, own, store and process, and convey information using all types of available channels. Another goal is to encourage public participation in the process of public policy making and enhance the active role of the community in public policy making and good management of public bodies[1]. Furthermore, in the implementation of a good State that is transparent, effective and efficient, accountable and can be accounted for. So that you can see the basis and purpose broadly related to Law No. 14 of 2008 concerning Openness of Public Information in article 2 and article 9 namely (2), every public information is open and can be accessed by every public information holder. Whereas (9), every public body is obliged to publish public information periodically, public information as intended includes: information related to public bodies, information about the activities and performance of related public bodies, information about financial statements, and other information that is regulated in subsequent legislation, the obligation to provide and convey public information as intended is carried out at least once every 6 months and, the obligation to disseminate public information is conveyed in a manner that is easily accessible to the public and in language that is easily understood. In this case it is associated with openness regarding management of village funds in Maumbi Village, which is regulated in Permendagri 113 of 2014 concerning Village Financial Management. The existence of these rules provides an opportunity for the community to fulfill their rights to participate in, or policy making by the government.

Openness of public information is an important element in the realization of good governance or good governance in the administration of government. The overall characteristics or principles of good governance are mutually reinforcing and interrelated and cannot stand alone. Information disclosure is important because in a closed government process that is prone to irregularities such as KKN. In Law No. 6 of 2014 concerning Villages, the rights and obligations of villagers directly or indirectly involved are regulated.

In Permendagri No 113/2014 concerning village financial management there are 4 principles used as indicators in implementing village financial management, which are based on the principles of transparency, accountability, participation and order and budget discipline. As for the management there are parts of planning, implementation, administration and accountability as outlined in the realization report and the accountability report on the realization of the ABPDesimplementation is informed to the public in writing with information media that is easily accessed by the public. One of the villages in North Minahasa Regency, Maumbi Village, received a village fund of Rp. $616,596,000$ (six hundred sixteen million five hundred ninety six thousand rupiah) in 2016[5]. 
Associated with the condition of North Minahasa District Officials as a place of research, programs conducted sourced from village funds in 2016 have been implemented but in the disclosure of information only related to certain instruments that control the information, especially in the management of the village funds themselves. The programs of the village funds contained in the 2016 APBDesa including management do exist but are only kept as a document in the village office, the launch of the 1 year running fund in 2016 starting from planning to accountability has not been informed to the community but has not been interpreted as proof of management such as the breakdown of the use of village funds. Even if there is a right of the community to ask questions or ask for information, it has not been received as expected. Departing from this, the researcher wants to see the extent of the government's openness towards the community due to the fact that the government has not fully implemented the provisions contained in Permendagri No.113 of 2014 concerning Village Financial Management.

There are some people who do not know the village budget which is allocated from the APBN. The village government has also not been able to provide information on both implementation and accountability as referred to in Minister of Domestic Affairs Regulation No. 113/2014 article 40 concerning Village Finance Managers regarding village funds, for example in the form of notice boards at the village office or in every village environment or other information media. So that the implementation accountability report has not been carried out properly. From the description above background by looking at the existing conditions, the researcher is interested in conducting research on "Public Information Openness in North Minahasa Regency".

Based on the background described above, the formulation of the problem can be stated, namely: 1). How open is public information regarding village fund management in North Minahasa Regency? ; 2). What factors are hampering the implementation of public information disclosure policies regarding village fund management in North Minahasa Regency?

\section{RESEARCH METHODS}

\section{1) Research Sites}

This research was conducted in North Minahasa Regency, North Sulawesi, Indonesia.

\section{2) Research Methods}

The method used in this study is a qualitative research method. Qualitative research is essentially research used to examine natural conditions or natural settings. In qualitative research, collecting data by observing people in their environment, interacting with them, trying to understand their language and interpretation of the world around them[2].

\section{3) Data Sources}

Primary data is data obtained directly from informants who are considered to know about the problem at hand.

Secondary data is data obtained from journal books or other information related to microbusiness development.
4) Data Collection Techiques Observation

Observation is a way of making direct observations of the object under study in order to obtain material related to the object so that it can obtain the necessary data.

Interview

Interviews were conducted directly with key informants and other supporting informants about the implementation of public information disclosure policies regarding village fund management in North Minahasa Regency. This was done with the aim of obtaining accurate data to answer the research focus.

Documentation

Documentation that aims to increase the credibility or the degree of trustworthiness of the results of research that can be in the form of pictures, as well as important notes relating to the object of research.

5) Data Validity Test

In testing the validity of the data, the researchers used 3 criteria, viz[2] :

1. Degree of Trust (Credibility)

This criterion serves to carry out the inquiry in such a way that the level of confidence in the findings can be achieved, demonstrating the degree of trust in the findings by proving by the researcher to the multiple facts being investigated.

2. Laterness (Transferability)

Intersection as an empirical issue depends on the similarity of the context of the sender and receiver.

3. Addiction(Dependebility)and certainty (Confirmability)

Kertegantung according to conventional terms is called reliability. Reliability is a requirement for validity, only with a reliable tool will valid data be obtained.

\section{RESULTS AND DISCUSSION}

Implementation of Public Information Openness Policy on Village Fund Management in North Minahasa Regency.

From the results of this study it was concluded to be interpreted regarding public information disclosure regarding village financial management with Permendagri 113 in 2014 namely:

(1) Village financial management can be concluded that transparent indicators are not in accordance with the mandate of Permendagri 113 of 2014, which should be that village finance sourced from the APBN can be known and monitored by all authorized parties who have the rights in this matter. Lack of understanding of these regulations from government officials regarding Permendagri 113 in 2014 on Village Financial Management so that they do not yet have legitimacy from the community and as a result of the lack of 
understanding of these rules, many questions arise regarding village funds sourced from the 2016 State Budget for their lack of transparency in management. Public.

(2) From the results of research conducted by researchers using accountable indicators it can be concluded that the forms of accountability for financial management of the winning villages already existed, however, the village government prioritized accountability to superiors in this case meant the district government namely the Regent while the village government overridden information realization of reports and accountability for the implementation of village funds in the form of project boards, notice boards for details of fund management, or accessible media that the government must provide when obtaining funds or the implementation of these funds in various programs / activities.

(3) (3) Village financial management can be concluded regarding participatory indicators that the lack of community roles to mutually control village financial management so that the results of development are not in accordance with community needs. Because of course the participation of the community is important in the realization of a program that is concerned with the interests of the community. Lack of community participation directly or indirectly through representative institutions that can accommodate and channel their aspirations, namely the BPD (Regional Representatives Council).

(4) (4) Village financial management which is concluded by orderly indicators and budget discipline, has not yet taken into account the discipline of using village budget funds in addition to being in accordance with the priority needs of the village community as well as how the budgeting has not involved experts in planning the development in order to prevent overuse of funds so that some needs may will not be achieved. There has not been any consistency from the village government in processing village finance sourced from the 2016 state budget. Because in North Minahasa Regency there are still village potentials that can be prioritized regarding community interests so that the community itself can feel the form of development carried out year after year. the same development prioritized so that the village government has not been able to see the other potentials.

Factors hampering the implementation of the Public Information Openness Policy on Village Fund Management in North Minahasa Regency.

\section{Communication Indicator}

The socialization has never been carried out by the district government but is only limited to the provision of theory to fulfill work programs and does not cover all levels of society because the socialization carried out just goes away without understanding the important points contained therein especially in the management of village finances namely the management of the Village Fund sourced from the state budget so that there are gaps in socialized rules which are only limited to formalities which result in regulations from the 113 Minister of Home Affairs Regulation on Village Financial Management which have not been realized properly and have not been effective because the authorities have not clearly and correctly understood.

2. Indicators of policy implementation

Existing resources include a lack of knowledge and education in the village government that is still lacking in processing existing facilities so that even though the facilities are already supporting but minimal knowledge in processing these facilities will have an effect on the governance process, especially in the management of village funds.

3. The third indicator of disposition

From the village officials who also manage village finances, there is an old law as the holder of power and the TPK that helps have not been able to explain and describe in detail about village funds and their use while the community is only focused by looking at developments that are manifested in village funds so that the community itself is only deceived by government elites.

4. Bureaucratic structure indicators

Supervision from the village head so that PTPKD who helps the village head has not been able to do his job properly in terms of preparing, implementing, controlling and reporting on the implementation plan of activities for which he is responsible. The researchers saw that the village government itself carried out an implementation report and an accountability report of the implementation but it was not in accordance with the regulations that became the reference in Permendagri 113/2014.

\section{CONCLUSION}

Based on the research results obtained that in Permandagri $113 / 2014$ on village financial management has not been applied in managing village funds in North Minahasa Regency and the implementation of managed village funds is not yet known by the community and the rights as a community are not fulfilled and access information regarding accountability in managing funds village.

After it was discovered that the Implementation of the Information Openness Policy on Village Financial Management in its implementation was not optimal, the obstacle was that the socialization carried out by the North Minahasa District Government regarding the management of village funds was not yet effective so that the government and the village community did not properly understand the contents of Permendagri $113 / 2014$ on management village finance, lack of competent resources that affect the performance of village governments that are less effective because of the level of education and lack of knowledge in processing existing facilities such as electronic media or in utilizing the internet / social media available to inform and facilitate work, attitudes of policy implementers tend to be closed regarding the management of village funds so they do not care about openness to the whole community. So that in reality the information on the use of village 
funds is only known by the government elites or only stored as documents in the village office so that it seems closed, the village government including the Technical Implementer does not understand (SOP) or Standard Operating Procedures so that the role in its management is only dependent on just one actor so that the tasks shared cannot be well directed.

\section{ACKNOWLEDGMENT}

The author would like to acknowledge the Dean of Faculty of Social Science, Manado State University in sipporting the publication of this article.

\section{REFERENCES}

[1] J. Mantiri, "The Impact of Public Participation Towards Waste Management In Tataaran Patar Village of South Tondano District," J. Ilm. Adm. Publik, 2018.

[2] Sugiyono, "Research methods," Method. Researcher., 2014
[3] Government of the Republic of Indonesia, "Law No. 6 of 2014 concerning Villages," a copy of Law No. 6 of 2014, 2014

[4] Guide to Understanding the Law of the Republic of Indonesia Number 14 Year 2008 concerning Openness of Public Information, Directorate of Institutional Communication of the Government, Directorate General of Communication and Information Dissemination Facilities Ministry of Communication and Information Technology Republic of Indonesia, Jakarta, 2008, page 3 .

[5] Maumbi Village Regulation No. 2 of 2016 concerning APBDes of the 2016 Budget Year.

[6] Permendagri No. 113 of 2014 concerning Village Financial Managers. 